\title{
Effect of Foliar Application of Ammonium Molybdate on Seed Quality of Soybean (Glycine max. (L.) Merrill.)
}

\author{
N. Harshika Netha*, D. B. Deosarkar, G. S. Pawar and S. V. Kalyankar \\ Department of Agricultural Botany, College of Agriculture, VNMKV, \\ Parbhani- 431402 (MS.), India \\ *Corresponding author
}

\section{A B S T R A C T}

Keywords

Foliar application,

Ammonium

molybdate, Quality

Article Info

Accepted:

04 September 2019

Available Online:

10 October 2019
With the aim to evaluate the effect of foliar application of ammonium molybdate on seed quality of soybean variety MAUS-158, a field experiment was carried out at Vasantrao Naik Marathwada Krishi Vidyapeeth during 2017-2018. The seven treatments consisting of different concentrations of ammonium molybdate i.e. $\mathrm{T}_{1}-0.4 \%, \mathrm{~T}_{2}-0.6 \%, \mathrm{~T}_{3}-0.8, \mathrm{~T}_{4^{-}}$ $1.0 \%, \mathrm{~T}_{5}-1.2 \%, \mathrm{~T}_{6}-1.4 \%$ and $\mathrm{T}_{7}$-control was applied at 40 and 60 DAS were tested in randomized block design with four replications. Results revealed that germination percentage, root and shoot length, seedling fresh and dry weight, vigour index, seed size showed a significant promotive effect with $1.0 \%$ ammonium molybdate concentration. $\alpha$-amylase and dehydrogenase activity were recorded to be highest in treatment $\mathrm{T}_{4}$. Increasing concentration of ammonium molybdate above $1.0 \%$ decreased promotive effect in soybean for most seed quality characters.

\section{Introduction}

Soybean (Glycine max L.) is the wonder crop of the $20^{\text {th }}$ Century, a species of legume, native to China, which belongs to family leguminoaceae with sub family Papilionaceae.

It was introduced in India during 1960's and is gaining rapid recognition as a highly desirable oil seed crop. Soybean as an indispensable source of plant protein is become more vital.
The seed supplies $30 \%$ of world vegetable oil and $60 \%$ of vegetable protein. Soybean seed consists of 18-22 percent oil and 40-42 percent protein content.

It is the cheapest and main source of dietary protein of majority of vegetarian (hence it is known as poor man's meat). In Maharashtra soybean production during kharif 2017 was 31.89 lakh MT from an area of 34.48 lakh hectares with the productivity of $925 \mathrm{~kg} \mathrm{ha}^{-1}$ 
(Anonymous 2017). Foliar application of nutrients is an important crop management strategy in maximizing crop yields.

When nutrients are applied to soils, they are absorbed by plant roots and translocated to aerial parts.

In case of foliar application, the nutrients penetrate the cuticle of the leaf or the stomata and enter the cells.

Hence, crop response occurs in short time in foliar application compared to soil application.

Foliar spray of the micronutrients is more effective and fast-acting than soil application (Gupta and Lipsett, 1981).

Macronutrients, which are required in high amounts by crop plants are rarely met by foliar application. Hence, so far the most important use of foliar sprays has been in the application of micronutrients.

Among the micronutrients that are essential for the plant growth, molybdenum is required in small amounts. It is a constituent of the nitrate reductase and nitrogenase enzyme, and every bacteria which fixes nitrogen needs molybdenum during the fixation processes.

Molybdenum has a positive effect on yield, quality and nodules forming in legume crops. The functions of molybdenum in leguminous plants include nitrate reduction, nodulation, nitrogen fixation and general metabolism (Togay et al., 2008).

\section{Materials and Methods}

The study was carried out at the Department of Agricultural Botany, College of Agriculture, VNMKV, Parbhani during June 2017 to October 2017. Foliar application of ammonium molybdate (54\% Mo content) with different concentrations $\left(\mathrm{T}_{1}-0.4 \%, \mathrm{~T}_{2}-\right.$ $0.6 \%, \mathrm{~T}_{3}-0.8 \%, \mathrm{~T}_{4}-1.0 \%, \mathrm{~T}_{5}-1.2 \%, \mathrm{~T}_{6}-1.4 \%$, and $\mathrm{T}_{7}$-control) at 40 and 60 days after sowing.

\section{Germination percentage}

Three replications of hundred seeds of each treatment were germinated using rolled paper method in seed germinator at $25^{\circ} \mathrm{C}$ temperature and $80 \%$ relative humidity (ISTA, 1999).

\section{Germination (\%) \\ Number of normal seedlings \\ Number of seeds planted}

\section{Root and Shoot length (cm)}

Ten normal seedlings selected randomly in each treatment from all the replications on tenth day of germination test and their average was recorded in centimeters.

\section{Fresh and Dry weight (g)}

Ten normal fresh seedlings was selected randomly for root and shoot length weighed on electronic balance and mean fresh weight of seedlings was recorded and expressed in grams.

The samples used for seedling fresh weight were dried in oven at $80^{\circ} \mathrm{C}$ for 24 hours followed by cooling for 30 minutes. The mean dry weight of the seedlings was recorded and expressed in grams.

\section{Vigour index}

Vigour index was calculated by using the formula suggested by Abdul-Baki and Anderson (1973).

Vigour index $=$ Germination $(\%) \times[$ Average root length $(\mathrm{cm})+$ Average shoot length $(\mathrm{cm})]$ 


\section{Moisture percentage}

Moisture percentage was recorded by using digital moisture meter. Average seed moisture of each treatment in all replications was determined and mean value was recorded.

\section{Seed size (mm)}

Seed size of soybean was measured by using vernier callipers.

Average seed size of randomly selected ten seeds was calculated in each treatment from all replications.

\section{$\alpha$-amylase activity $(\mathrm{mg} / \mathrm{g})$}

$\alpha$-amylase activity was recorded as per the procedure given by Juliano, B.O. (1971).

Results were recorded as one unit of $\alpha$ amylase is expressed as $\mathrm{mg}$ of maltose released per min per gm of sample.

\section{Dehydrogenase activity $(\mu \mathrm{g} / \mathrm{g})$}

Dehydrogenase enzyme activity was recorded as per the procedure given by Thimaya (1990).

Results were recorded as one unit of dehydrogenase is expressed as ug TPF $\mathrm{h}^{-1} \mathrm{~g}^{-1}$ standard curve released per min per gm of sample.

\section{Protein content (\%)}

Protein content was estimated by using KEL PLUS Nitrogen Estimation System.

$$
\% \text { Nitrogen }=\frac{14.01 \times 0.1 \times(\mathrm{TV}-\mathrm{BV}) \times 100}{\text { wt. of sample }(\mathrm{gm}) \times 1000}
$$

Protein $\%=\mathrm{N} \% \times 6.25$

\section{Oil content (\%)}

Oil content was estimated by using NMR (Nuclear Magnetic Resonance) technique (Alexander et al., 1967).

\section{Results and Discussion}

\section{Germination (\%)}

Data pertaining to seed germination percentage is presented in Table 1 indicated that there were significant difference among the treatments with respect of seed germination percentage. It was noticed that the germination percentage decreased with increase in ammonium molybdate concentration above $1.0 \%$. The highest germination percentage was recorded in treatment $\mathrm{T}_{4}(93.78 \%)$. The results of the present investigation are in close conformity with findings of Hugar and Kurdikeri (2000) in soybean.

\section{Root length and Shoot length}

Highest root and shoot length was recorded in case of ammonium molybdate treated plants in comparison to control. The treatment $\mathrm{T}_{4}$ recorded highest root $(11.73 \mathrm{~cm})$ and shoot length $(13.40 \mathrm{~cm})$, respectively (Table 1).Beyond this treatment with increased concentration there was reduction in both root length and shoot length. However these treatments were significant over control. Present findings were similar with those reported by Datta et al., (2011) in bengal gram.

\section{Fresh weight and Dry weight}

Fresh weight and dry weight of seedlings were found to be significantly higher in ammonium molybdate treated plants with respect to control. Fresh weight and dry weight ranged between 0.64 and $0.06 \mathrm{~g}\left(\mathrm{~T}_{7}\right)$ and 0.87 and 
$0.10 \mathrm{~g}\left(\mathrm{~T}_{4}\right)$ respectively. The seedling fresh and dry weight was decreased with increase in concentration above $1.0 \%$. Highest fresh weight and dry weight was recorded in treatment $\mathrm{T}_{4}$ followed by $\mathrm{T}_{3}$ (Table 1 ).

These findings are in accordance with those reported by Bodi et al., (2015) in maize and sunflower seedlings and Datta et al., (2011) in bengal gram.

\section{Vigour index}

The data pertaining to vigour index have been presented in Table 1. The vigour index was decreased with increase in concentration of ammonium molybdate above $1.0 \%$.

Highest seedling vigour index was recorded in treatment $\mathrm{T}_{4}$ (2356.69) followed by $\mathrm{T}_{3}$ (2167.66). Present findings were found to be similar with those reported by Hugar and Kurdikeri (2000) in soybean and Sreedhara et al., (2012) in alfalfa.

\section{Moisture content}

Data (Table 4) showed that the applied treatments gave non significant results with respect to moisture content in seed.

\section{Seed size}

Seed size components i.e. length and width recorded significant results with foliar application of ammonium molybdate.

However the seed length and width declined with increase in concentration of ammonium molybdate.

Length and width found to be highest in treatment $\mathrm{T}_{4} \quad(7.48 \mathrm{~mm}$ and $7.25 \mathrm{~mm}$ respectively) over control $(6.75 \mathrm{~mm}$ and 6.47 $\mathrm{mm}$ respectively) (Table 2 ).

\section{$\alpha$-amylase activity}

Data pertaining to $\alpha$-amylase activity was presented in Table 3. From treatment $T_{1}$ to $T_{4}$ $\alpha$-amylase activity of ammonium molybdate treated plants gradually increased but from treatment $T_{5}$ it decreased. Highest $\alpha$-amylase activity was recorded in treatment $\mathrm{T}_{4}(12.64$ $\mathrm{mg} / \mathrm{g})$. These results are in accordance with those reported by Modi and carins (1995) in wheat.

\section{Dehydrogenase activity}

Data pertaining to dehydrogenase activity was presented in Table 3. Highest dehydrogenase activity was recorded in treatment $\mathrm{T}_{4}$ (98 $\mu \mathrm{g} / \mathrm{g}$ ). From treatment $T_{5}$ onwards a declining trend was found with respect to dehydrogenase activity.

The results of the present investigation are in close conformity with findings of Kaiser et al., (2005) reported that foliar fertilization of molybdenum increased dehydrogenase activity in crop production.

\section{Protein content}

The data of various treatments with respect to protein content is presented in Table 4 showed that the foliar application ammonium molybdate recorded non significant results in relation to protein content. The treatment $\mathrm{T}_{4}$ maximum oil content $(40.38 \%)$ followed by $\mathrm{T}_{3}(39.36 \%)$.

\section{Oil content}

Data pertaining to oil content is presented in Table 4 showed that the foliar application ammonium molybdate recorded non significant results in relation to oil content. The treatment $\mathrm{T}_{4}$ recorded maximum oil content $(19.81 \%)$ followed by $\mathrm{T}_{3}(19.55 \%)$. 
Table.1 Effect of foliar application of ammonium molybdate on germination (\%), root and shoot length, fresh and dry weight and vigour index

\begin{tabular}{|c|c|c|c|c|c|c|}
\hline Treatments & $\begin{array}{l}\text { Germination } \\
\%\end{array}$ & $\begin{array}{l}\text { Root } \\
\text { length } \\
\text { (cm) }\end{array}$ & $\begin{array}{l}\text { Shoot } \\
\text { length } \\
\text { (cm) }\end{array}$ & $\begin{array}{l}\text { Fresh } \\
\text { weight } \\
\text { (g) }\end{array}$ & $\begin{array}{l}\text { Dry } \\
\text { weight } \\
\text { (g) }\end{array}$ & $\begin{array}{l}\text { Vigour } \\
\text { index }\end{array}$ \\
\hline $\begin{array}{l}\mathrm{T}_{1} \quad \text { (Foliar application of } \\
\text { ammonium molybdate @ } 0.4 \%)\end{array}$ & 86.52 & 8.92 & 10.92 & 0.68 & 0.07 & 1716.55 \\
\hline $\begin{array}{l}\mathrm{T}_{2} \quad(\text { Foliar application of } \\
\text { ammonium molybdate @ } 0.6 \%)\end{array}$ & 88.42 & 9.84 & 11.63 & 0.74 & 0.09 & 1898.37 \\
\hline $\begin{array}{l}\mathrm{T}_{3} \quad \text { (Foliar application of } \\
\text { ammonium molybdate @ } 0.8 \%)\end{array}$ & 91.54 & 10.92 & 12.76 & 0.78 & 0.09 & 2167.66 \\
\hline $\begin{array}{l}\mathrm{T}_{4} \quad \text { (Foliar application of } \\
\text { ammonium molybdate @ } 1.0 \%)\end{array}$ & 93.78 & 11.73 & 13.40 & 0.87 & 0.10 & 2356.69 \\
\hline $\begin{array}{l}\mathrm{T}_{5} \quad(\text { Foliar application of } \\
\text { ammonium molybdate @ } 1.2 \%)\end{array}$ & 89.84 & 10.10 & 12.00 & 0.75 & 0.09 & 1985.46 \\
\hline $\begin{array}{l}\mathrm{T}_{6} \quad \text { (Foliar application of } \\
\text { ammonium molybdate @ } 1.4 \%)\end{array}$ & 87.68 & 9.38 & 11.18 & 0.71 & 0.08 & 1802.70 \\
\hline $\mathbf{T}_{7}$ (water spray) control & 84.00 & 8.40 & 10.25 & 0.64 & 0.06 & 1566.60 \\
\hline $\mathrm{SE}(\mathrm{m}) \pm$ & 1.15 & 0.19 & 0.19 & $\mathbf{0 . 0 3}$ & 0.008 & 92.58 \\
\hline CD at $5 \%$ & 3.43 & 0.59 & 0.59 & 0.10 & 0.025 & 277.21 \\
\hline
\end{tabular}

Table.2 Effect foliar application of ammonium molybdate on seed size

\begin{tabular}{|c|c|c|}
\hline Treatments & $\begin{array}{l}\text { Seed Length } \\
(\mathrm{mm})\end{array}$ & $\begin{array}{ll}\text { Seed } \\
(\mathrm{mm})\end{array}$ \\
\hline $\mathrm{T}_{1}$ (Foliar application of ammonium molybdate @ $0.4 \%$ ) & 6.87 & 6.62 \\
\hline $\mathrm{T}_{2}$ (Foliar application of ammonium molybdate @ $0.6 \%$ ) & 7.14 & 6.93 \\
\hline $\mathbf{T}_{3}$ (Foliar application of ammonium molybdate @ $0.8 \%$ ) & 7.31 & 7.10 \\
\hline $\mathbf{T}_{4}($ Foliar application of ammonium molybdate @ $1.0 \%)$ & 7.48 & 7.25 \\
\hline $\mathbf{T}_{5}$ (Foliar application of ammonium molybdate @ $\left.1.2 \%\right)$ & 7.15 & 6.96 \\
\hline $\mathbf{T}_{6}$ (Foliar application of ammonium molybdate @ $1.4 \%$ ) & 7.01 & 6.79 \\
\hline $\mathbf{T}_{7}$ (water spray) control & 6.75 & 6.47 \\
\hline $\mathrm{SE}(\mathrm{m}) \pm$ & 0.05 & 0.08 \\
\hline CD at $5 \%$ & 0.16 & 0.26 \\
\hline
\end{tabular}


Table.3 Effect of foliar application of ammonium molybdate on $\alpha$-amylase activity and dehydrogenase activity

\begin{tabular}{|c|c|c|}
\hline Treatments & $\begin{array}{c}\alpha \text {-amylase } \\
\text { activity (mg/g) }\end{array}$ & $\begin{array}{l}\text { Dehydrogenase } \\
\text { activity ( } \mu \mathrm{g} / \mathrm{g})\end{array}$ \\
\hline $\mathrm{T}_{1}$ (Foliar application of ammonium molybdate @ $0.4 \%$ ) & 10.57 & 82 \\
\hline $\mathbf{T}_{2}$ (Foliar application of ammonium molybdate @ $0.6 \%$ ) & 11.57 & 88 \\
\hline $\mathbf{T}_{3}$ (Foliar application of ammonium molybdate @ $0.8 \%$ ) & 12.33 & 95 \\
\hline $\mathbf{T}_{4}$ (Foliar application of ammonium molybdate @ $1.0 \%$ ) & 12.64 & 98 \\
\hline $\mathbf{T}_{5}$ (Foliar application of ammonium molybdate @ $\left.1.2 \%\right)$ & 12.24 & 92 \\
\hline $\mathrm{T}_{6}$ (Foliar application of ammonium molybdate @ $1.4 \%$ ) & 11.33 & 84 \\
\hline $\mathbf{T}_{7}$ (water spray) control & 9.3 & 75 \\
\hline $\mathrm{SE}(\mathbf{m}) \pm$ & 0.36 & 1.97 \\
\hline CD at $5 \%$ & 1.09 & 5.90 \\
\hline
\end{tabular}

Table.4 Effect of foliar application of ammonium molybdate on moisture content, protein content and oil content

\begin{tabular}{|c|c|c|c|}
\hline Treatments & $\begin{array}{l}\text { Moisture } \\
\text { content } \\
(\%)\end{array}$ & $\begin{array}{c}\text { Protein } \\
\text { content } \\
(\%)\end{array}$ & $\begin{array}{c}\text { Oil } \\
\text { content } \\
(\%)\end{array}$ \\
\hline $\mathrm{T}_{1}$ (Foliar application of ammonium molybdate @ $0.4 \%$ ) & 10.30 & 38.31 & 18.94 \\
\hline $\mathbf{T}_{2}$ (Foliar application of ammonium molybdate @ $0.6 \%$ ) & 9.90 & 38.85 & 19.29 \\
\hline $\mathrm{T}_{3}$ (Foliar application of ammonium molybdate @ $0.8 \%$ ) & 9.70 & 39.36 & 19.55 \\
\hline $\mathbf{T}_{4}$ (Foliar application of ammonium molybdate @ $1.0 \%$ ) & 9.64 & 40.38 & 19.81 \\
\hline $\mathrm{T}_{5}$ (Foliar application of ammonium molybdate @ $1.2 \%$ ) & 9.80 & 39.20 & 19.43 \\
\hline $\mathrm{T}_{6}$ (Foliar application of ammonium molybdate @ $1.4 \%$ ) & 10.10 & 38.50 & 19.21 \\
\hline $\mathbf{T}_{7}$ (water spray) control & 10.80 & 38.01 & 18.36 \\
\hline $\mathrm{SE}(\mathbf{m}) \pm$ & 0.39 & 1.41 & 0.64 \\
\hline CD at $5 \%$ & N.S & N.S & N.S \\
\hline
\end{tabular}


Fig.1
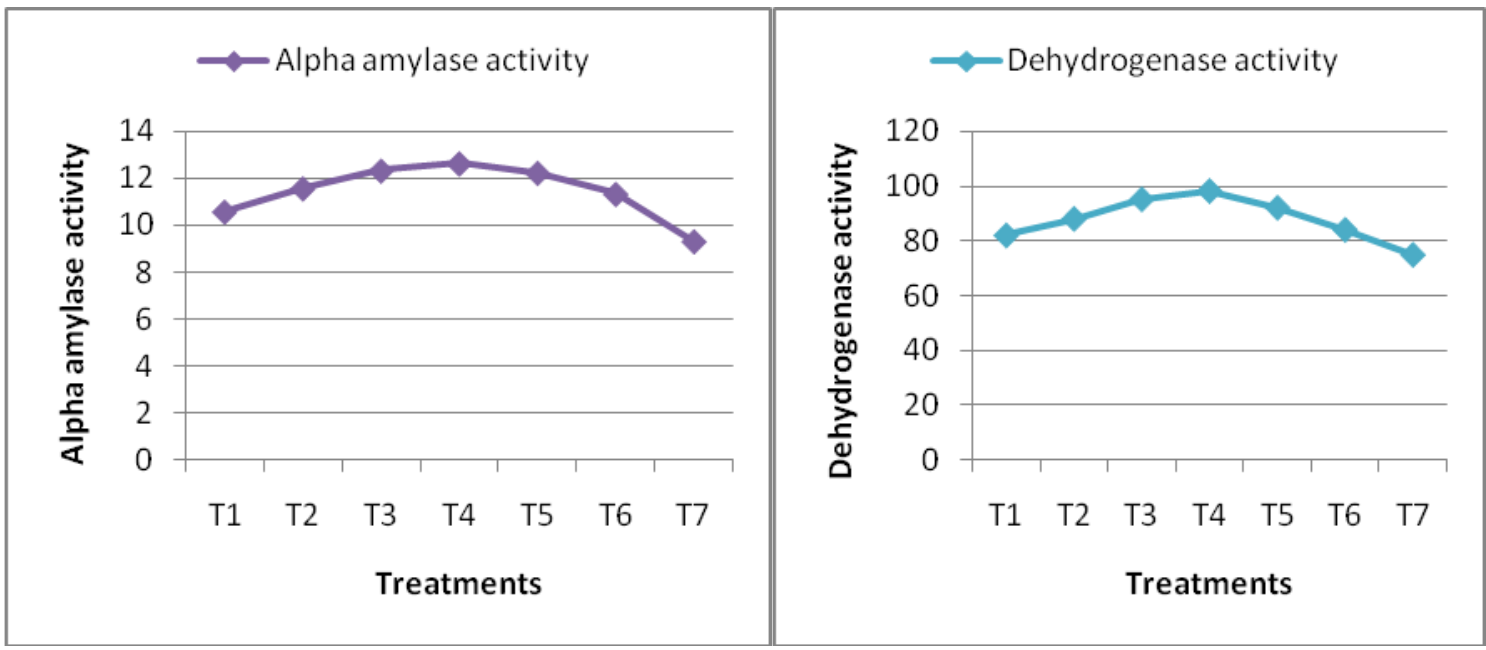

\section{References}

Anonymous. (2017). Area, production and productivity of soybean in India Kharif (monsoon) 2017-18. www.sopa.oer/crop.po.doc

Abdul-Baki, A. A and Anderson, J.D. (1973). Vigour determination in soybean seeds by multiple criteria. Crop Sci., 13: 630-633.

Alexander, D. E. (1967). Technique of nuclear and magnetic resonance (NMR). $J$. Am.Oil Chem. Soc., 44: 555.

Bodi, E., Veres, Sz., Garousi, F., Varallyay, Sz. and Kovacs, B. (2015). Effects of molybdenum treatments on maize and sunflower seedlings. International journal of agricultural and biosystems engineering. 9(5): 450-453.

Datta, J.K., Kundu, A., Hossein, S.D., Banerjee, A. and Mondal, N.K. (2011). Studies on the impact of micronutrient (Molybdenum) on germination, seedling growth and physiology of bengal gram (Cicer arietinum) under laboratory conditions. Asian J.Crop Sci., 3(2): 55-67.

Gupta, U. C. and Lipsett, 1981. Molybdenum in soils, plants and animals. $A d v$. Agron. 34: 73-115.
Hugar, A.B. and Kurdikeri, M.B. (2000). Effect of application methods and levels of zinc and molybdenum on seed yield and quality of soybean. Karnataka. J. Agril. Sci., 13(2): 442444.

ISTA, (1999). International rules for seed testing. Seed Sci. Tech., 27, supplement 2: pp-132.

Juliano B.O. (1971). He gave the procedure to assay the $\alpha$-amylase enzyme activity at 0, 30, 60 days.

Kaiser, B. N., Gridley, K. L., Brady, J. N., Phillips, T. and Tyerman, S. D. (2005). The role of molybdenum in agricultural plant production. Annals of Botany. 96: 745-754.

Modi, A.T. and Cairns, A.L.P. (1995). Can molybdenum reduce pre-harvest sprouting in wheat. S. Afr. Tydskr. Plant Grond. 12(3): 108-111.

Sreedhara, K., Krishna, A. and Harish, S. (2012). Influence of insect attractants, micronutrients and growth regulators on seed quality parameters in alfalfa (Medicago sativa L.). Forage Res., 38(2): 91-95.

Thimaya's book: "Fundamental of Biochemistry" for reference of $\alpha$ amylase and dehydrogenase enzyme 
activity.

Togay, Y., Togay, N. and Dogan, Y. (2008). Research on the effect of phosphorus and molybdenum applications on the yield and yield parameters in lentil (Lens culinaris Medic.). African Journal of Biotechnology. 7(9): 12561260.

\section{How to cite this article:}

Harshika Netha, N., D. B. Deosarkar, G. S. Pawar and Kalyankar, S. V. 2019. Effect of Foliar Application of Ammonium Molybdate on Seed Quality of Soybean (Glycine max. (L.) Merrill.). Int.J.Curr.Microbiol.App.Sci. 8(10): 95-102. doi: https://doi.org/10.20546/ijcmas.2019.810.011 